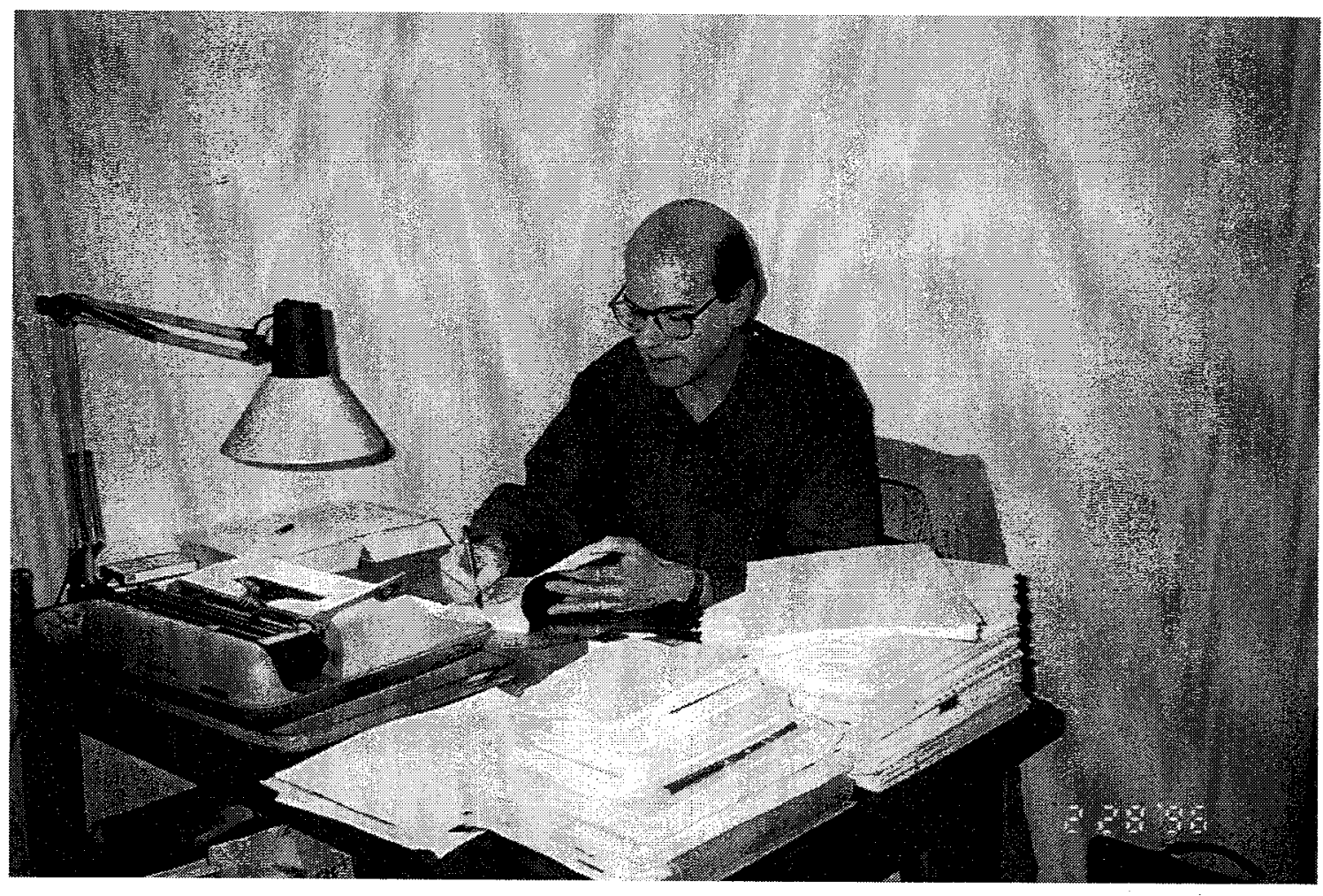

\title{
Christian Gailly
}

